\title{
TATA NIAGA PEMASARAN AYAM PEDAGING POLA MANDIRI DI KECAMATAN RASAU JAYA KABUPATEN KUBU RAYA KALIMANTAN BARAT
}

\section{Trading System Analysis of Broiler Chicken with Self-Operating Model in Rasau Jaya Sub-District, Kubu Raya District, West Kalimantan}

\author{
Angga Permadi Karpriana ${ }^{1}$, Yuli Arif Tribudi ${ }^{2}$ \\ ${ }^{1}$ Faculty of Economic and Business, Universitas Tanjungpura \\ ${ }^{2}$ Faculty of Agriculture, Universitas Tanjungpura \\ Jl. Prof. Dr. H. Hadari Nawawi 78124 \\ E-mail : permadiangga@me.com
}

\begin{abstract}
Livestock is one of the agricultural sub-sectors. Currently, broiler farming business attacks have many attention for researchers to be studied. Trading system becomes an integral part in the entire business activity, so do in broiler farming business. The trading system in broiler farming business is included in the downstream agribusiness sub-system so the farmers are able to be easier in distributing their livestock products to consumers. The aim of this study was to evaluate the trading system of broiler chicken with self-operating model in Rasau Jaya sub-district, Kubu Raya district, West Kalimantan from January to March 2018. Total of 32 livestock keepers and 8 traders were used as samples. Both of the primary and secondary data were collected. This study was performed using descriptive survey method. Snowball sampling method was also applied for sample collection. Trading system of broiler farming business in the studied location is divided into two channels. Channel I consisted of breeders, collectors, consumers, while Channel II consisted of farmers, collectors, retailers, consumers. It could be concluded that channel II was more complex than Channel 1 because in Channel II there was a retailer that had a function as intermediary between traders and consumers.
\end{abstract}

Keywords: Broiler Chicken, Farming Bussiness, Marketing, Self-Operating Model, Trading System

\section{PENDAHULUAN}

Peternakan merupakan salah satu subsektor pertanian, usaha yang menarik untuk dikaji di subsektor peternakan ini adalah usaha ayam ras pedaging. Prospek pasar dan pengembangan agribisnis ayam ras pedaging di Indonesia baik pada subsistem hulu, subsistem budidaya, maupun subsistem hilir sangat terbuka lebar (Saragih, 2000). Peningkatan jumlah penduduk di Indonesia setiap tahunnya menyebabkan semakin meningkatnya tingkat konsumsi pangan khususnya daging ayam.

Kalimantan Barat khususnya Kabupaten Kubu Raya, sektor pertanian menjadi salah satu sektor penopang perekonomian yang memberikan kontribusi PDRB (Produk Domestik Regional Bruto) Kabupaten Kubu Raya yang cukup signifikan, yakni sebesar $17,88 \%$ dari total PDRB (Badan Pusat Statistik Kabupaten Kubu Raya, 2018), termasuk didalamnya sektor peternakan. Produk peternakan yang merupakan bahan pangan yang dapat memenuhi kebutuhan dasar manusia untuk memenuhi kebutuhan gizi masyarakat yang bersumber dari protein hewani berupa daging, telur, dan susu. Daging ayam pedaging khususnya, mempunyai peranan penting sebagai sumber protein hewani yang dibutuhkan mayoritas penduduk sehingga kebutuhan akan daging ayam yang berkualitas ikut meningkat.

Sistem Peternakan di daerah Kubu Raya memilik dua sistem, yaitu sistem peternak mandiri dan sistem peternak kemitraan. Menurut Nuraeni et al. (2006), peranan peternak juga sangat menentukan dalam memenuhi kebutuhan pasokan daging ayam. Usaha peternakan ayam dapat dijalankan dengan usaha secara mandiri dan kerjasama, yaitu sistem kemitraan. Usaha peternakan ayam pedaging yang dijalankan dengan tidak melakukan kemitraan disebut peternak mandiri, yaitu semua sarana dan prasarana produksi dipenuhi sendiri oleh peternak dan semua permasalahan dalam kegiatan peternakan ditanggung secara pribadi oleh 
peternak, begitu juga dengan risiko yang dihadapi peternak mandiri akan ditanggung secara keseluruhan oleh peternak tersebut.

Tataniaga merupakan suatu bagian yang tidak dapat dipisahkan dari seluruh kegiatan usaha, begitu pula halnya dengan usaha peternakan ayam pedaging. Tataniaga ayam pedaging termasuk ke dalam subsistem agribisnis hilir, kegiatan ini dapat membantu peternak dalam menyalurkan hasil ternaknya agar sampai kepada konsumen (Chopra and Meindl, 2007). Tataniaga ayam pedaging melibatkan berbagai lembaga tataniaga. Aktivitas tataniaga yang dilakukan oleh setiap lembaga tataniaga akan memberikan nilai tambah bagi komoditas yang diperjualbelikan (Kohls and Uhl, 2002). Nilai tambah yang dihasilkan perlu didistribusikan secara adil sesuai dengan faktor-faktor produksi yang digunakan sehingga nilai tambah dapat dirasakan oleh setiap lembaga tataniaga yang terlibat.

\section{MATERI DAN METODE}

Penelitian dilaksanakan di Kecamatan Rasau Jaya Kabupaten Kubu Raya, Provinsi Kalimantan Barat pada bulan Januari sampai Maret 2018. Lokasi penelitian ditentukan secara purposive dengan pertimbangan bahwa kecamatan tersebut merupakan daerah potensial dengan perkembangan ternak ayam ras pedaging yang relatif besar di Kabupaten Kubu Raya. Jumlah sampel sebanyak 32 peternak mandiri dan 8 pedagang. Pedagang yang dimaksud ialah pedagang pengumpul dan pedagang eceran yang menjual ayam ras pedaging. Metode yang digunakan dalam pengambilan sampel untuk pedagang menggunakan snowball sampling.

Data yang dikumpulkan dalam penelitian ini adalah data primer dan data sekunder. Data primer diperoleh dari pengajuan kuisioner kepada peternak ayam ras pedaging, pedagang pengumpul dan pedagang eceran yang akan ditelusuri selama penelitian. Data sekunder diperoleh dari Badan Pusat Statistik dan Dinas Ketahanan Pangan Perkebunan dan Peternakan Kubu Raya. Analisis yang digunakan adalah analisis deskriptif untuk menganalisis saluran tataniaga ayam ras pedaging.

\section{HASIL DAN PEMBAHASAN}

Saluran tataniaga merupakan serangkaian aktivitas yang dilakukan oleh lembaga-lembaga tataniaga yang terlibat dalam proses alur suatu produk barang yang dipasarkan, mulai dari produsen yaitu peternak hingga ke konsumen akhir (Danniel, 2004). Saluran tataniaga ayam pedaging di Kecamatan Rasau Jaya melibatkan dua lembaga tataniaga, yaitu pedagang pengumpul dan pedagang pengecer. Sistem tataniaga ayam pedaging pola mandiri di Kecamatan Rasau Jaya diperoleh dua saluran tataniaga ayam pedaging, yaitu saluran tataniaga I yang terdiri atas : Peternak $\rightarrow$ Pedagang pengumpul $\rightarrow$ Konsumen, dan saluran tataniaga II yang terdiri atas: Peternak $\rightarrow$ Pedagang pengumpul $\rightarrow$ Pedagang pengecer $\rightarrow$ Konsumen.

\section{Pola Saluran Tataniaga I}

Saluran tataniaga I merupakan saluran tataniaga yang melibatkan peternak dengan lembaga tataniaga, sehingga terbentuk saluran dengan pola yaitu peternak - pedagang pengumpul - konsumen. Sejumlah 32 peternak yang menjadi responden dalam saluran tataniaga I ini, terdapat 18 orang peternak mandiri yang menjual hasil panennya kepada pedagang pengumpul yang kemudian mendistribusikan langsung hasil panen tersebut yang berupa ayam pedaging hidup kepada konsumen. Pada saluran I ini yang menjadi konsumen adalah rumah makan maupun perorangan.

Biaya pemasaran yang dikeluarkan oleh pedagang pengumpul meliputi biaya pengangkutan dari peternak, biaya pemotongan ayam, dan biaya penjualan hingga sampai ke konsumen. Peternak yang menjual ayam pedaging langsung ke pedagang pengumpul merupakan peternak dengan jumlah pemeliharaan ayam yang dipelihara berkisar antara 800 hingga 3.000 ekor per siklus pemeliharaan, yaitu selama 25 hari dengan rataan bobot hidup sewaktu dilakukan pemanenan berkisar $1,24 \mathrm{~kg}$.

Kematian ayam adalah sesuatu yang tidak dapat dihindari, baik karena penyakit atau faktorfaktor lain. Biasanya peternak menetapkan batas maksimal kematian yang dapat ditoleransi yaitu sebesar 5\%. Semakin banyak ayam yang mati, maka semakin besar kerugian peternak. Persentase maksimal kematian ayam selama proses pemeliharaan berlangsung yaitu sebesar $5 \%$, sehingga jumlah panen peternak pada saluran ini berkisar antara 760 hingga 2850 ekor. Angka jumlah panen diperoleh dari jumlah ayam yang dipelihara dikalikan dengan persentase kematian, yaitu 5\% dan dikalikan jumlah ayam yang dipelihara pada awal pemeliharaan di saluran ini.

Peternak yang menjual ayam pedaging melalui pedagang pengumpul biasanya tidak perlu mengeluarkan biaya transportasi untuk pengangkutan hasil panen. Hal ini terjadi karena hasil panen peternak dijemput langsung oleh pedagang pengumpul ke kandang milik peternak. 
Oleh karena itu, biaya transportasi ditanggung oleh pedagang pengumpul. Ketika melakukan pemanenan dan penimbangan bobot ayam serta pengangkutan hasil panen dari kandang ke kendaraan pedagang pengumpul, tenaga kerja yang digunakan berasal dari peternak yaitu pegawai kandang. Sistem pembelian yang dilakukan oleh pedagang pengumpul adalah sistem borongan.

Pedagang pengumpul yang menjadi responden dalam saluran tataniaga I ini berjumlah 7 orang. Ayam pedaging yang diterima oleh pedagang pengumpul selanjutnya disimpan di kandang penampungan milik mereka. Selanjutnya, mereka melakukan pemotongan ayam untuk kemudian dijual dalam bentuk daging ayam utuh atau dapat juga dengan konsumen, yaitu rumah makan maupun perorangan yang membeli langsung ayam pedaging dari pedagang pengumpul, dimana ayam di jual dalam bentuk hidup (live bird) atau mati yang sudah dibersihkan kulitnya (daging ayam utuh) tanpa melewati fungsi pengolahan. Konsumen yang membeli merupakan konsumen lokal yang berdomisili di sekitar pedagang pengumpul di kawasan Rasau Jaya.

\section{Pola Saluran Tataniaga II}

Saluran tataniaga II merupakan saluran yang melibatkan peternak, pedagang pengumpul, pedagang pengecer dan konsumen. Perbedaan saluran tataniaga II dengan saluran tataniaga I adalah adanya lembaga tataniaga yaitu pedagang pengecer (pedagang yang menjual keliling kampung atau pedagang tidak tetap yang biasanya menjual daging di pinggir jalan pasar) sebagai perantara antara pedagang pengumpul dengan konsumen.

Peternak pada saluran ini tetap menjual hasil panen mereka berupa ayam pedaging hidup kepada pedagang pengumpul sama seperti pada saluran tataniaga I. Peternak menjual hasil panennya kepada pedagang pengumpul dikarenakan peternak tidak perlu memasarkan sendiri hasil panennya, sehingga tidak mengeluarkan biaya pengangkutan.

Ayam pedaging yang dijual ke pedagang pengumpul kemudian diangkut dan disimpan oleh pedagang pengumpul di kandang penampungan milik mereka. Ayam pedaging yang dikumpulkan oleh pedagang pengumpul kemudian dipotong lalu daging ayam yang dihasilkan didistribusikan kepada pedagang pengecer dalam bentuk karkas atau potongan kecil. Selanjutnya, dari pedagang pengecer tersebut daging ayam pedaging yang telah melewati proses pengolahan dapat sampai ke tangan konsumen. Peternak yang menjadi responden pada saluran ini berjumlah 6 orang, yang terdiri dari 4 orang pedagang pengumpul dan 15 orang pedagang pengecer.

Peternak pada saluran ini memelihara ayam dengan jumlah pemeliharaan berkisar dari 1.500 hingga 7.000 per siklus pemeliharaan, yaitu 25 hari, dengan rataan bobot panen $1,24 \mathrm{~kg}$. Biaya pemasaran yang dikeluarkan oleh pedagang pengumpul meliputi biaya pengangkutan dari peternak, biaya pemotongan ayam, dan biaya penjualan ke pedagang pengecer, sedangkan biaya pemasaran yang dilakukan oleh pedagang pengecer adalah biaya pengangkutan dari pedagang pengumpul, dan biaya penjualan hingga sampai ke tangan konsumen.

Fungsi tataniaga yang dilakukan oleh lembaga-lembaga tataniaga ayam pedaging pada setiap saluran tataniaga ayam pedaging pola mandiri di Kecamatan Rasau Jaya Kabupaten Kubu Raya dapat dilihat pada Tabel 1 bahwa fungsi pertukaran yaitu penjualan dan pembelian dilakukan oleh semua pihak yang terlibat pada sistem saluran tataniaga ayam pedaging di Kecamatan Rasau Jaya. Komoditi yang diperjualbelikan adalah ayam pedaging. Pada saluran I dan II produk akhir yang dijual kepada konsumen adalah ayam pedaging dalam kondisi hidup (live bird) tanpa melawati proses pengolahan, dan karkas (daging ayam tanpa darah, kepala, ceker, bulu dan jeroan) yaitu ayam pedaging yang telah melewati proses pengolahan.

Fungsi fisik berupa fungsi pengangkutan dilakukan oleh lembaga-lembaga, antara lain pedagang pengumpul dan pedagang pengecer (Sumantri et al., 2013). Pengangkutan dilakukan untuk memindahkan barang yang dibeli dari pihak yang menjual kepada pihak yang membeli. Barang yang telah dipindahkan tersebut selanjutnya disimpan, sehingga terdapat biaya penyimpanan. Biaya penyimpanan dan pakan dikeluarkan oleh pedagang pengumpul, baik pada saluran I dan II. Pada saluran ini, biaya penyimpanan yang dikeluarkan oleh pedagang pengecer berupa biaya penyimpanan karkas yang tersisa selama proses penjualan (Arumugam and Mojtahedzadeh, 2011).

Fungsi fisik selanjutnya adalah fungsi pengolahan yang dilakukan oleh pedagang pengecer pada saluran II serta pedagang pengumpul pada saluran I dan II. Pengolahan dilakukan dalam rangka mengubah ayam pedaging hidup menjadi karkas yang selanjutnya akan dijual kepada konsumen. Kegiatan ini menjadi nilai tambah bagi barang yang diperjualbelikan. 
Tabel 1. Fungsi Tataniaga Masing-masing Lembaga Tataniaga dalam Sistem Tataniaga Ayam Pedaging di Kecamatan Rasau Jaya

\begin{tabular}{|c|c|c|c|c|c|c|c|c|c|}
\hline \multirow{3}{*}{$\begin{array}{c}\text { Saluran dan } \\
\text { Lembaga } \\
\text { Tataniaga }\end{array}$} & \multicolumn{9}{|c|}{ Fungsi Tataniaga } \\
\hline & \multicolumn{2}{|c|}{$\begin{array}{c}\text { Fungsi } \\
\text { Prtukaran }\end{array}$} & \multicolumn{4}{|c|}{ Fungsi Fisik } & \multicolumn{3}{|c|}{ Fungsi Fasilitas } \\
\hline & Jual & Beli & Angkut & Simpan & Olah & Risiko & Biaya & $\begin{array}{c}\text { Informasi } \\
\text { pasar }\end{array}$ & $\begin{array}{l}\text { Sortasi/ } \\
\text { Grading }\end{array}$ \\
\hline Saluran 1 & & & & & & & & & \\
\hline Peternak & $\sqrt{ }$ & - & - & - & - & $\sqrt{ }$ & $\sqrt{ }$ & $\sqrt{ }$ & - \\
\hline $\begin{array}{l}\text { Pedagang } \\
\text { pengumpul }\end{array}$ & $\sqrt{ }$ & $\sqrt{ }$ & $\sqrt{ }$ & $\sqrt{ }$ & $\sqrt{ }$ & $\sqrt{ }$ & $\sqrt{ }$ & $\sqrt{ }$ & - \\
\hline Saluran II & & & & & & & & & \\
\hline Peternak & $\sqrt{ }$ & - & - & - & - & $\sqrt{ }$ & $\sqrt{ }$ & $\sqrt{ }$ & - \\
\hline $\begin{array}{l}\text { Pedagang } \\
\text { pengumpul }\end{array}$ & $\sqrt{ }$ & $\sqrt{ }$ & $\sqrt{ }$ & $\sqrt{ }$ & $\sqrt{ }$ & $\sqrt{ }$ & $\sqrt{ }$ & $\sqrt{ }$ & - \\
\hline $\begin{array}{l}\text { Pedagang } \\
\text { pengencer }\end{array}$ & $\sqrt{ }$ & $\sqrt{ }$ & $\sqrt{ }$ & $\sqrt{ }$ & - & $\sqrt{ }$ & $\sqrt{ }$ & $\sqrt{ }$ & - \\
\hline
\end{tabular}

Fungsi risiko ditanggung oleh semua pihak pada sistem saluran tataniaga ayam pedaging di Kecamatan Rasau Jaya. Peternak menghadapi resiko harga yang fluktuatif dan tidak tentu setiap harinya. Kerugian terjadi jika harga jual peternak berada dibawah Farm Gate Price (FGP).

Resiko yang dihadapi pedagang pengumpul adalah resiko harga yang fluktuatif yang menyebabkan pasang surutnya penjualan ayam pedaging dan resiko kematian (Sumpe, 2009), juga resiko ketika dilakukan proses pengangkutan dan penyimpanan serta pengembalian yang telat dibayarkan oleh pedagang pengecer langganan mereka dimana hal ini mempengaruhi pedagang pengumpul dalam menjalankan kegiatan usahanya.

Resiko yang dihadapi oleh pedagang pengecer terjadi jika terdapat karkas yang tidak terjual dalam satu hari dan ketika dijual kembali keesokan harinya tetap tidak laku terjual, maka pedagang pengecer mengalami kerugian sejumlah harga beli karkas tersebut, termasuk resiko kematian ayam ketika dilakukan pengangkutan pada saluran II.

\section{SIMPULAN}

Berdasarkan hasil penelitian dapat disimpulkan bahwa tataniaga pemasaran ayam pedaging pola mandiri di Kecamatan Rasau Jaya, Kabupaten Kubu Raya terdiri dari dua saluran, yaitu saluran I terdiri dari Peternak $\rightarrow$ Pedagang Pengumpul $\rightarrow$ Konsumen, dan Saluran II terdiri dari Peternak $\rightarrow$ Pedagang Pengumpul $\rightarrow$ Pedagang Pengecer $\rightarrow$ Konsumen.

\section{DAFTAR PUSTAKA}

Arumugam, V. C., and R. Mojtahedzadeh. 2011. Relationship between supply chain management practices and performance in the Iranian industries: A theoretical approach. Int. J. Aca. Res.3(4): 594-636.

Badan Pusat Statistik Kabupaten Kubu Raya. 2018. Kabupaten Kubu Raya Dalam Angka. Kubu Raya.

Chopra, S., and P. Meindl. 2007. Supply Chain Management: Strategy, Planning and Operations. Third Edition. Pearson Pretince Hall. New Jersey.

Danniel, M. 2004. Pengantar Ekonomi Pertanian. Bumi Aksara. Jakarta

Kohls, R. L., and J. N. Uhl. 2002. Marketing of Agricultural Products. Ninth Edition. Prentice-Hall, Inc. New Jersey.

Nuraeni, Purwanta, dan Wahyuni. 2006. Efisiensi Pemasaran Ayam Buras di Desa Kalebarembeng, Kecamatan Bontonopo, Kabupaten Gowa. J. Agrisistem 2(2): 68-73.

Saragih, B. 2000. Kumpulan Pemikiran: Agribisnis Berbasis Peternakan. Cetakan Kedua. Pustaka Wirausaha Muda. PT. Loji Grafika Griya Sarana. Bogor.

Sumantri, J.T., A. Kusumastuti, dan W. Rini. 2013. Pemasaran ternak sapi potong di Kabupaten Ogan Komering Ilir, Sumatera Selatan. Bul. Pet. 37(1): 49-58.

Sumpe, I. 2009. Faktor-faktor yang mempengaruhi margin pemasaran ternak sapi potong di Kabupaten Manokwari. J. Ilmu Pet. .4(2): 93-98. 